\title{
Leading Different Dimensions of Organization Performance through Human Resource Management Practices
}

\author{
Nazanin Mansouri (Corresponding author) \\ ELM Graduate School, HELP University \\ Damansara Heights, 50490 Kuala Lumpur, Malaysia \\ Email: nazanin_mansouri89@yahoo.com \\ Khaled Goher \\ Department of Informatics and Enabling Technologies, Lincoln University \\ Lincoln 7647, Canterbury, New Zealand
}

Received: September 26, 2016 Accepted: October 21, 2016 Published: December 01, 2016

doi:10.5296/ijhrs.v6i4.10336 URL: http://dx.doi.org/10.5296/ijhrs.v6i4.10336

\begin{abstract}
The primary purpose of this research work is to find out how human resource management practices including training, staffing, performance appraisal, participation, and reward system can affect the performance of Malaysian Information and Communication Technology (ICT) companies. Company's performance is identified in this work in terms of innovation, learning and growth, and internal process. The results of analysis of 223 gathered data showed that human resource management practices have significant and positive impact on innovation, learning and growth, and internal process. In addition, this study showed that performance components can affect each other significantly and positively. In this research work, the data is collected through questionnaire and analyzed by Statistical Package for the Social Sciences (SPSS) software. Moreover, the respondents of this research work are the employees of small and medium size ICT companies located in Cyberjaya, Malaysia.
\end{abstract}

Keywords: Human Resource Management (HRM) practices, Innovation, Learning and growth, Internal process, Malaysia, ICT companies. 


\section{Introduction}

Information and communication technology (ICT) has become a substantial part of the modern world. ICT is used throughout the world to a point that it is changing the technological and the cultural facet of the communities nowadays (Mentz et al., 2012).However, the technological transformation has forced labors to adapt to changes particularly in terms of fulfilling requirements needed by said industry. Because of this, ICT scholars who are equipped with certain qualifications are highly demanded. However, despite the vast growing of institutions administering courses and training in this industry, requirements are still failing to be fulfilled (Adam Suhaimi et al., 2012). As a solution to this, necessary steps should be taken to assist to solve the imbalance of supply and demand. If this issue is not resolved, it may cause problems for both business organizations as well as academic institutions.

In accordance with Malaysia's vision in 2020, there has been noticeable abrupt development in ICT infrastructure (Lau and Sim, 2008; Sin et al., 2010; Hassan et al., 2011; Bajunid, 2012; Bohari et al., 2013; Tang and Tan, 2014).Research studies which have been conducted recently in this field present that the primary determinant of the growth of ICT is innovation(Toppeta, 2014; Peschl and Fundneider, 2014), whereas it can affect the efficiency of certain corporations, particularly Balanced-Score Card perspectives as said by Kaplan and Norton (1995).One dependable method to determine rate of efficiency is the Balanced-Score Card perspectives (BSC) (Hojabri et al., 2013; Borousan et al., 2011). In BSC, there are four important perspectives that should be taken into consideration. They are customer satisfaction, financial performance, internal process, and learning and growth. Three of the said factors do not involve any financial aspect. Furthermore, the implication of innovation towards non-financial factors has been well accepted in researches. Thus, it can be deduced that innovation gives a rather significant effect to corporation's performance (Kanter, 2015; Senge, 2014; Ellis and Goodyear, 2013; Aguilera-Caracuel and Ortiz-de-Mandojana, 2013). Despite all the proven usefulness of innovation in ICT and the significant affect it's giving to corporation's performance, it seems that this issue is not getting enough attention than it should by business organizations and researchers in Malaysia. Resource-based view (RBV) of the organization has been well understood as one of the major method to help in developing continuous competitive advantage. RBV stresses on the connection between the firm's internal resources, especially human resource (HR) and its effectiveness (Barney, 1991) that can help in providing an upper hand compared to its competitors.

A great number of research studies are conducted to prove this matter. For instance, engaging a meta-analysis of Huselid (1995) indicates the effect of HR on the efficiency of the firm's financial situation; Chen and Huang (2009) have also established that knowledge management capacity and innovation performance is determined by HRM practices. However, research studies that have been conducted of late, have proven the significant effect HR has on knowledge sharing and innovation (Manafi and Subramaniam, 2015a). Consequently, the ultimate function of knowledge in an organization's financial situation by promoting innovative change has been proven numerous times in many studies. The economical switch from material-based production to information-based production have caused a complete 
reinterpretation of the organization making it the main reason that knowledge is considered as a critical resources of said organization (Manafi and Subramaniam, 2015a). Because of this, RBV can be called Knowledge based view (KBV) of the organization mainly assuming that it is not easily duplicated and that it is different than one another (Grant, 1996; Cabrera-Suarez et al., 2001; Felin et al., 2007; Blome et al., 2014).

\subsection{Overview and Contribution}

Considering the previous mentioned studied, the authors can conclude that both RBV and $\mathrm{KBV}$ prove the influence of HRM on the overall performance of the organization; especially on innovation.HRM practices have considerable potential to affect the performance of Malaysian ICT companies. However, the impact of HRM practices on different aspects of performance (innovation, internal process, and learning and growth) is not clear. Besides, the internal relationships of performance's components need to be discussed in more. Hence, this research paper aims at answering the following two questions:

- How HRM practices affect innovation, internal process, and learning and growth?

- How the three of performance components are correlated?

\subsection{Paper Organization}

This paper is organized as follows: Section 2 presents a review of related work in practices of human resource management and the relation to organizational performance. Methodology and results are presented in Section 3 and the paper is concluded in Section 4.

\section{Related Work}

\subsection{Practices of Human Resource Management}

In their respective researches, Schuler and Jackson (1995), Wright and Snell (1991), and Schuler and Mac Millan (1984), they have reported that human resources are regarded as the complete organizational activities that helps manage human resource pool (HR) while making sure that these resources are working accordingly so that the organization's aims and objectives are achieved. Table 1 depicts the varied facets of HRM practices identified by professionals and researchers in this industry.

\subsection{Human Resource Management Practices and Organizational Performance}

The advantage of HRM on the organizations' performance is well understood and has been reported in many studies. Researchers discovered that there are beneficial connection between HRM practices and organizational performance (MacDuffie, 1995; Becker and Gerhart, 1996; Delery and Doty, 1996; Huselid, 1995). In their researches, these scholars pursued to focus on various prospects of innovative HRM practices. They then correlated these prospects and determined the advantages and disadvantages. From this analysis, professionals in this field could choose for the optimum approach to be used. As stated by Delery and Doty (1996) in their research, having HRM being introduced to the industry have led to many establishments attempting to engage in these practices. By applying these practices, many have expressed that at a cheaper cost, higher revenue was achieved. With all 
the positive feedbacks being reported back, many have decided to turn their heads towards this field.

Aside from that, Terpstra and Rozell (1993) analyzed 2012 companies in their human resource related activities such as: availability of gauging system for Return On Investment (ROI) and recruitment source, validity gauging regarding pre-employment assessment, standardized and structured interviews, intelligence assessment and biographic Information or Weighted Application. Based on their analysis, it was shown that organizations that engage in HRM practices has higher profit margin. They reported that a notably practical connection is present between level of implementation of five different policies for both staffing and organization's prosperities. Comparison was done to understand the yearly growth of sample population before and after deploying HRM practices. The study reached to a conclusion that shows the significant performance increase prompted by these practices. Data from various countries were gathered and analyzed. It was found that the rate of change varies in different countries. In a similar study, Chen and Huang (2009) analyzed the effect of seminars, performance appraisal, staffing and participation and award system on knowledge management capacity and technical innovation.

able 1: Various HRM Practices Defined by Different Researchers

\begin{tabular}{|c|c|}
\hline Scholars & Practices of Human Resource Management \\
\hline Huselid (1995) & $\begin{array}{l}\text { Performance evaluation; staffing; job design; incentive } \\
\text { compensation; grievance procedures; attitude evaluation; } \\
\text { information sharing; contribution; hiring efforts; promotion; } \\
\text { training and development }\end{array}$ \\
\hline Pfeffer (1998) & $\begin{array}{l}\text { Selective recruitment; members of staff security; } \\
\text { contribution; training and development; rewarding; profit } \\
\text { sharing; decreased status distinctions }\end{array}$ \\
\hline Huang (2000) & $\begin{array}{l}\text { Planning; staffing; rewarding; performance evaluation; } \\
\text { training and development }\end{array}$ \\
\hline $\begin{array}{l}\text { Tessema and } \\
\text { Soeters }(2006)\end{array}$ & $\begin{array}{l}\text { Placement; hiring and selection; training and development; } \\
\text { performance assessment; rewarding; grievance procedures; } \\
\text { promotion; pension and social safety }\end{array}$ \\
\hline $\begin{array}{l}\text { Chen and } \\
\text { Huang (2009); } \\
\text { Manafi and } \\
\text { Subramaniam } \\
(2015 a ; b)\end{array}$ & $\begin{array}{l}\text { Staffing; training and development; performance } \\
\text { assessment; rewarding; contribution }\end{array}$ \\
\hline
\end{tabular}




\begin{tabular}{|l|l|}
\hline Others & $\begin{array}{l}\text { safety; satisfying working environment; open house } \\
\text { discussion; feedback mechanism; open management; } \\
\text { delight members of staff with unexpected; etc }\end{array}$ \\
\hline
\end{tabular}

Manafi and Subramaniam (2015a) took into consideration various theories inclusive of RBV, social capital, social exchange and transformational leadership to examine the connection between different HRM disciples and transformational leadership with knowledge sharing and innovation. Their outcome was the role of knowledge sharing that is already proven in numerous studies previously. They also came with knowledge being an important influence on innovation improvement. While pursuing new approaches to help choosing the optimum HRM disciples, Manafi and Subramaniam (2015b) came up with the agreement that with suitable selection topped with implementation of HRM disciples, a firm's performance can be monitored, and consequently improved. They evaluated the organization's effectiveness based on the BSC perspectives. Fuzzy logic neural network and AHP method was the basis of their suggested approach. Based on all the results of all said studies, we can safely confirm that whether HRM practices are effective or not depends on the industry that it is implemented on. In addition, taking BSC perspectives into consideration can greatly help examine performance of organization. Innovation has also been marked as an important factor that affects the performance making it to be considered as an additional aspect while evaluating performance. However, it was found in previous researches that transformational leadership also plays an important role in the relation between HRM disciples and organizational performance. In such a way, this study pursues to examine the function of transformational leadership and how it affects the connection between HRM disciples and overall performance. This is a very newly developed issue which is not receiving enough attention to be taken care of.

\section{Methods and Results}

This research study targeted senior and junior employees of small and medium size of ICT companies in Malaysia. The questionnaire was distributed amongst ten ICT companies and 223 responses were received. The SPSS software has been used to analyze the collected data.

Figure 1 shows the proposed framework which has been developed in accordance with RBV and KBV theories. In order to test the provided framework, a quantitative approach was used. First, all of the relevant hypotheses should be developed as followings. Moreover, each hypothesis should be break down into sub-hypothesis.

D1: HRM practices have significant and positive relationship with Performance

- H1a: HRM practices have significant impact on innovation

- H1b: HRM practices have significant impact on learning and growth

- H1c: HRM practices have significant impact on internal process 


\section{Macrothink}

International Journal of Human Resource Studies

ISSN 2162-3058 2016, Vol. 6, No. 4

$>$ H2: Innovation has a significant and positive effect on learning and growth

$>$ H3: Innovation has a significant and positive effect on internal process

$>$ H4: Internal process has a significant and positive effect on innovation

$>$ H5: Internal process has a significant and positive effect on learning and growth

$>$ H6: Learning and growth has as significant and positive effect on innovation

H7: Learning and growth has a significant and positive effect on internal process

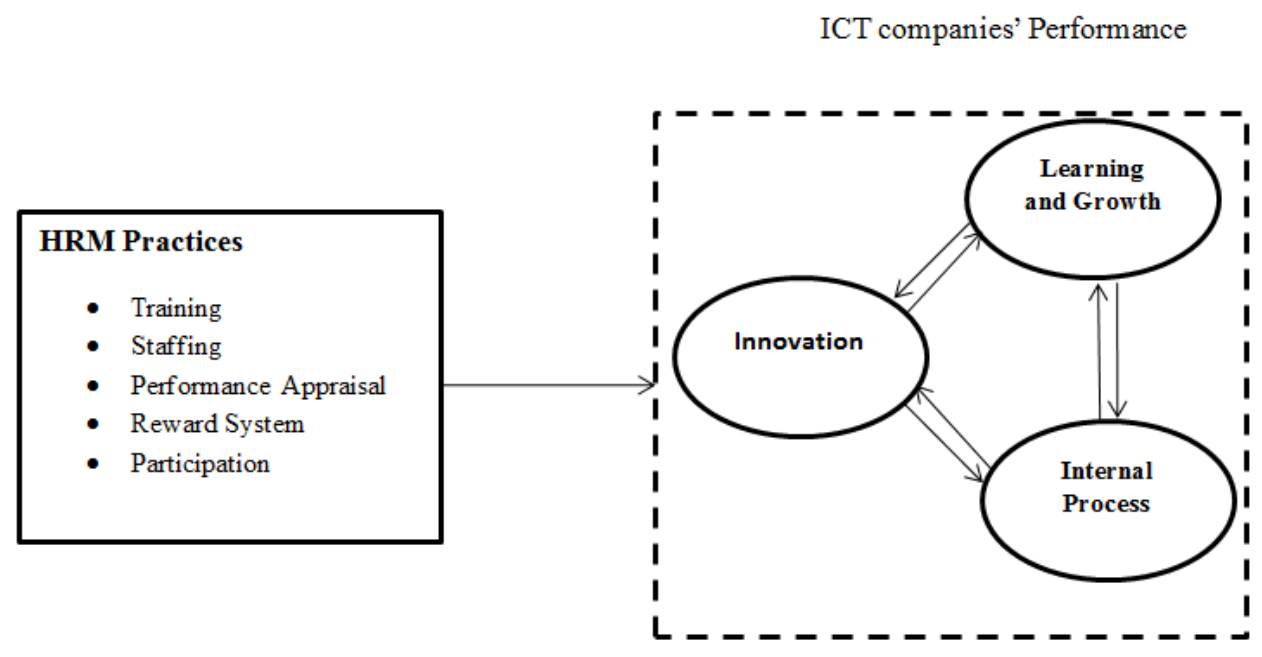

Figure 1: Proposed Framework

To measure innovation and HRM practices, this research adapted items from the research conducted by Manafi and Subramaniam (2015a). The items of internal process and learning and growth were developed based on the existing items of BSC (Kaplan and Norton, 1995).

For the purpose of examining the above hypothesis, primary data was utilized. Primary data was gained by distributing questionnaire amongst targeted respondents. In order to measure the variables, 5-point Likert Scale was applied. The population of this study consisted of all the middle and chief management of ICT companies locating in Cyberjaya - Malaysia. By the table of Krejcie and Morgan (1970), 270 questionnaires were distributed. At the end, 223 usable data was analyzed by SPSS 22.

The results of reliability test showed that there is an acceptable internal consistency for each construct because all estimated values for Cronbach's Alpha were greater than .78 (according to the Nunally (1978) the acceptable values vary between 0.7 and 1.00). Table 2 shows the mean analysis of each construct. 
Table 2: Mean Analysis

\begin{tabular}{lllll}
\hline Variable & Mean & SD & Skewness & Kurtosis \\
HRM practices & 4.01 & 0.9651 & -.299 & -0.777 \\
Innovation & 3.87 & 0.8704 & -.033 & -0.891 \\
Learning and Growth & 3.65 & 0.7652 & -.179 & -0.435 \\
Internal Process & 3.27 & 0.9696 & -.543 & -0.367 \\
\hline
\end{tabular}

Referring to Table 1, the highest estimated mean (4.01) refers to HRM practices while the lowest value (3.27) refers to internal process. However, all means are greater than 3.00 which assert that most of the respondents' answers converge to "agree". The negative signs of skewness show that all of the peaks (in frequency charts) are centralized to the right direction. Besides, the negative signs of kurtosis show that every variable has flat distribution. Table 3 demonstrates the results of exploratory factor analysis (EFA) for dependent variables of this study.

Table 3: Summary of EFA

\begin{tabular}{lcc}
\hline Innovation & $\mathbf{1}$ & $\mathbf{3}$ \\
Novel and useful processes and products are developed by my company & .767 & \\
Novel and useful processes are successfully implemented by my company & .755 & \\
Novel and useful processes and products have become a stable and regular part of the & .721 & \\
organization & .711 \\
Developing new technologies is important for my company & .703 \\
My company incorporates new technologies into new products & .694 \\
My company facilitates new processes to improve quality and cost & .677 & \\
My company changes when it is necessary & \\
Learning & .882 \\
Employees receive adequate training to do their job well & .843 \\
Using new technology teaches employees many new things & .832 \\
By exploiting new technology, our company grows & .821 \\
Our company learns and grows by managing existing knowledge inside the company & .799 \\
Our company applies the necessary knowledge from out of company as well & .765 \\
By using new technology, our company has improved their products' qualities & \\
Internal Process & \\
Our employees are happy with their jobs & \\
Using new technology increases employees' job satisfaction & .832 \\
Our employees are very much committed to the company & .800 \\
Usage of networks facilitates internal process for both employees and company & .795 \\
Our employees trust company's decisions & \\
Our employee participates in implementation of new managerial practices towards usage \\
of new technologies
\end{tabular}




\section{Mll Macrothink}

International Journal of Human Resource Studies

ISSN 2162-3058 2016, Vol. 6, No. 4

The estimated value of $\mathrm{KMO}(\mathrm{Df}=1565$; $\mathrm{P}$-value $=0.00)$ is equal to .801 , so it is acceptable according to the Pett et al. (2003). So, all of the developed items can be applied for further analyses. The results of Pearson correlation test can be seen in the table 4:

Table 4: Pearson Correlation Test

\begin{tabular}{lllll}
\hline Variable & $(1)$ & $(2)$ & $(3)$ & (4) \\
$\begin{array}{l}\text { (1) HRM practices } \\
\text { (2) Innovation }\end{array}$ & 1.00 & & \\
$\begin{array}{l}\text { (3) Learning } \\
\text { Growth }\end{array}$ & and & $0.563^{* *}$ & 1.00 & \\
\\
(4) Internal Process & $0.701^{* * *}$ & $0.441^{* *}$ & 1.00 \\
\hline
\end{tabular}

**: $99 \%$ confidence

The last analysis is regression analysis. The outcome of regression analysis helps to accept/reject the developed hypotheses. Table 5 shows the summary of regression analyses. It can be noticed from the table that all of the hypotheses are accepted by this study. The obtained results are consistent with extant research conducted by previous scholars (as mentioned in literature review).

\section{Conclusion}

The obtained results showed that HRM practices can significantly affect innovation, learning and growth, and internal process. By considering innovation, learning and growth, and internal process as components of performance, the results are consistent with extant research conducted by Huselid (1995), Chen and Huang (2009), and Manafi and Subramaniam (2015a, b). On the other hand, the interactions between these components are supported by this study. By the results of regression analysis, Malaysian ICT companies can increase the level of innovation through HRM practices. Besides, proper implementation of HRM practice will improve internal processes and thereby learning and growth.

It is evident that there has been a noticeable and abrupt development in technology; therefore, it is significant for companies to maintain sustainable innovation and learning growth. Moreover, there is a stiff rivalry amongst competitors of each industry. For this reason, future study can test the proposed framework of this study in other scopes or industries such as manufacturing industry with the purpose of not only boosting company's performance, but also ameliorating company's position to surpass the rivals. 
Table 5: Regression Analysis

\begin{tabular}{|c|c|c|c|c|c|c|}
\hline Effects & Hypothesis & Coefficient & SE & t-value & $\begin{array}{l}\text { Sig } \\
\text { (P-value) }\end{array}$ & Supported \\
\hline HRM-Inn & $\begin{array}{l}\text { H1a: } \\
\text { practices } \\
\text { significant impact } \\
\text { on innovation }\end{array}$ & 0.467 & 0.087 & 5.32 & 0.000 & Yes \\
\hline HRM-L\&G & $\begin{array}{l}\text { H1b: } \\
\text { practices }\end{array}$ & 0.511 & 0.046 & 11.01 & 0.000 & Yes \\
\hline $\begin{array}{l}\text { HRM-Int. } \\
\text { Process }\end{array}$ & $\begin{array}{l}\text { H1c: } \\
\text { practices } \\
\text { significant impact } \\
\text { on internal process }\end{array}$ & 0.691 & 0.030 & 23.01 & 0.001 & Yes \\
\hline Inn-L\&G & $\begin{array}{l}\mathrm{H} 2 \text { : Innovation has } \\
\text { a significant and } \\
\text { positive effect on } \\
\text { learning and growth }\end{array}$ & 0.544 & 0.095 & 5.67 & 0.004 & Yes \\
\hline $\begin{array}{l}\text { Inn- Int. } \\
\text { Process }\end{array}$ & $\begin{array}{l}\text { H3: Innovation has } \\
\text { a significant and } \\
\text { positive effect on } \\
\text { internal process }\end{array}$ & 0.398 & 0.079 & 4.98 & 0.002 & Yes \\
\hline $\begin{array}{l}\text { Int. } \\
\text { Process- } \\
\text { Inn }\end{array}$ & $\begin{array}{l}\text { H4: Internal process } \\
\text { has a significant and } \\
\text { positive effect on } \\
\text { innovation }\end{array}$ & 0.601 & 0.085 & 6.99 & 0.000 & Yes \\
\hline $\begin{array}{l}\text { Int. } \\
\text { Process- } \\
\text { L\&G }\end{array}$ & $\begin{array}{l}\text { H5: Internal process } \\
\text { has a significant and } \\
\text { positive effect on } \\
\text { learning and growth }\end{array}$ & 0.324 & 0.094 & 17.01 & 0.006 & Yes \\
\hline L\&G- Inn & H6: Learning and & 0.365 & 0.106 & 3.44 & 0.017 & Yes \\
\hline
\end{tabular}




\begin{tabular}{|c|c|c|c|c|c|c|}
\hline & $\begin{array}{lr}\text { growth has as } \\
\text { significant and } \\
\text { positive effect on } \\
\text { innovation }\end{array}$ & & & & & \\
\hline $\begin{array}{l}\text { L\&G- Int. } \\
\text { Process }\end{array}$ & $\begin{array}{lr}\text { H7: Learning and } \\
\text { growth has a } \\
\text { significant and } \\
\text { positive effect on } \\
\text { internal process }\end{array}$ & .412 & 0.067 & 6.07 & 0.011 & Yes \\
\hline
\end{tabular}

\section{References}

Adam Suhaimi, M., RabiulHasan, M., Hussin, H., \& Shah, A. (2012). Information and communication technology workforce employability in Malaysia. Campus-Wide Information Systems, 29(2), 80-89.

Aguilera-Caracuel, J., \& Ortiz-de-Mandojana, N. (2013). Green Innovation and Financial Performance An Institutional Approach. Organization \& Environment, 26(4), 365-385.http://dx.doi.org/10.1177/1086026613507931.

Barney, J. (1991). Firm resources and sustained competitive advantage. Journal of management, 17(1), 99-120. http://dx.doi.org/10.1177/014920639101700108.

Bajunid, I. A. (2012). The transformation of Malaysian society through technological advantage: ICT and education in Malaysia. Journal of Southeast Asian Education, 2(1).

Becker, B., \& Gerhart, B. (1996). The impact of human resource management on organizational performance: Progress and prospects. Academy of Management Journal, 39(4), 779-801. http://dx.doi.org/10.2307/256712.

Blome, C., Schoenherr, T., \& Eckstein, D. (2014). The impact of knowledge transfer and complexity on supply chain flexibility: A knowledge-based view. International Journal of Production Economics, 147, 307-316. http://dx.doi.org/10.1016/j.ijpe.2013.02.028.

Bohari, A. M., Cheng, W. H., \&Fuad, N. (2013). An analysis on the competitiveness of halal food industry in Malaysia: an approach of SWOT and ICT strategy. Geografia: Malaysian Journal of Society and Space, 9(1), 1-11.

Borousan, E., Hojabri, R., Manafi, M., \&Hooman, A. (2011).Balanced Scorecard: A tool for measuring and modifying IT Governance in Healthcare organizations. International Journal of Innovation, Management and Technology, 2(2), 141.

Cabrera-Suárez, K., De Saa-Perez, P., \&García-Almeida, D. (2001).The succession process from a resource-and knowledge-based view of the family firm. Family Business Review, 14(1), 37-46. http://dx.doi.org/10.1111/j.1741-6248.2001.00037.x. 


\section{Macrothink}

International Journal of Human Resource Studies

ISSN 2162-3058

2016, Vol. 6, No. 4

Chen, C. J., \& Huang, J. W. (2009). Strategic human resource practices and innovation performance-The mediating role of knowledge management capacity. Journal of Business Research, 62(1), 104-114. http://dx.doi.org/10.1016/j.jbusres.2007.11.016.

Delery, J. E., \& Doty, D. H. (1996). Modes of theorizing in strategic human resource management: Tests of universalistic, contingency, and configurational performance predictions. Academy of management Journal, 39(4), 802-835. http://dx.doi.org/10.2307/256713.

Ellis, R., \& Goodyear, P. (2013). Students' experiences of e-learning in higher education: the ecology of sustainable innovation. Routledge.

Felin, T., \&Hesterly, W. S. (2007). The knowledge-based view, nested heterogeneity, and new value creation: Philosophical considerations on the locus of knowledge. Academy of Management Review, 32(1), 195-218. http://dx.doi.org/10.5465/AMR.2007.23464020.

Grant, R. M. (1996). Toward a knowledge-based theory of the firm. Strategic management journal, 17(S2), 109-122. http://dx.doi.org/10.1002/smj.4250171110.

Hassan, M. A., Samah, B. A., Shaffril, H. A. M., \&D'Silva, J. L. (2011). Perceived usefulness of ICT usage among JKKK members in Peninsular Malaysia. Asian Social Science, 7(10), p255. http://dx.doi.org/10.5539/ass.v7n10p255.

Hojabri, R., Manafi, M., Eftekhar, F., Ghassemzadeh, H., Sharifi, M., \&Kaliannan, M. (2013). Effective methods for health care organizations: An evaluation of excellence models. African Journal of Business Management, 7(27), 2665-2675. http://dx.doi.org/10.5897/AJBM11.2747.

Huang, T. C. (2000). Are the human resource practices of effective firms distinctly different from those of poorly performing ones?,The International Journal of Human Resource Management, http://dx.doi.org/10.1080/095851900339945.

Huselid, M. A. (1995). The impact of human resource management practices on turnover, productivity, and corporate financial performance. Academy of management journal, 38(3), 635-672. http://dx.doi.org/10.2307/256741.

Kanter, R. M. (2015). From spare change to real change: The social sector as beta site for business innovation. Havard Business Review.

Kaplan, R. S., \& Norton, D. P. (1995). Putting the balanced scorecard to work. Performance measurement, management, and appraisal sourcebook, 66, 17511.

Krejcie, R. V., \& Morgan, D. W. (1970). Determining sample size for research activities. Educpsychol meas.

Lau, B. T., \& Sim, C. H. (2008).Exploring the extent of ICT adoption among secondary school teachers in Malaysia. International Journal of Computing and ICT research, 2(2), 19-36. 


\section{Macrothink}

International Journal of Human Resource Studies

ISSN 2162-3058

2016, Vol. 6, No. 4

MacDuffie, J. P. (1995). Human resource bundles and manufacturing performance: Organizational logic and flexible production systems in the world auto industry. Industrial \& labor relations review, 48(2), 197-221. http://dx.doi.org/10.1177/001979399504800201.

Manafi, M., \&Subramaniam, I. D. (2015a). Balancing performance by human resource management practices. Asian Social Science, 11(10), 386.

Manafi, M., \&Subramaniam, I. D. (2015b). Balancing Performance by Human Resource Management Practices. Asian Social Science, 11(10), p386.

Mentz, E., Bailey, R., Havenga, M., Breed, B., Govender, D., Govender, I., ...\&Dignum, V. (2012). The diverse educational needs and challenges of Information Technology teachers in two black rural schools. Perspectives in Education, 30(1), 70.

Peschl, M. F., \&Fundneider, T. (2014). Designing and enabling spaces for collaborative knowledge creation and innovation: From managing to enabling innovation as socio-epistemological technology. Computers in Human Behavior, 37, 346-359. http://dx.doi.org/10.1016/j.chb.2012.05.027.

Pett, M. A., Lackey, N. R., \& Sullivan, J. J. (2003). Making sense of factor analysis: The use of factor analysis for instrument development in health care research.Sage.

Pfeffer, J. (1998). The human equation: Building profits by putting people first. Harvard Business Press.

Schuler, R. S., \& Jackson, S. E. (1995). Understanding human resource management in the context of organizations and their environment. Annual Review of Psychology, 46(1), 237-264.

Schuler, R. S., \& MacMillan, I. C. (1984). Gaining competitive advantage through human resource management practices. Human Resource Management, 23(3), 241-255. http://dx.doi.org/10.1002/hrm.3930230304

Senge, P. M. (2014). The dance of change: The challenges to sustaining momentum in a learning organization. Crown Business.

Sin Tan, K., Choy Chong, S., Lin, B., \& Cyril Eze, U. (2010). Internet-based ICT adoption among SMEs: Demographic versus benefits, barriers, and adoption intention. Journal of enterprise information management, 23(1), 27-55.

Tang, C. F., \& Tan, B. W. (2014). The linkages among energy consumption, economic growth, relative price, foreign direct investment, and financial development in Malaysia. Quality \& Quantity, 48(2), 781-797. http://dx.doi.org/10.1007/s11135-012-9802-4.

Terpstra, D. E., \&Rozell, E. J. (1993). The relationship of staffing practices to organizational level measures of performance. Personnel Psychology, 46(1), 27-48. http://dx.doi.org/10.1111/j.1744-6570.1993.tb00866.x

TeclemichaelTessema, M., \&Soeters, J. L. (2006). Challenges and prospects of HRM in developing countries: testing the HRM-performance link in the Eritrean civil service. The 
international journal of human resource management, 17(1), 86-105.

Toppeta, D. (2014). The Smart City Vision: How Innovation and ICT Can Build Smart. Livable", Sustainable Cities", The Innovation Knowledge Foundation. Available from http://www.intaaivn.org/images/cc/Urbanism/background\%20documents/Toppeta_Report_ 005_2010.pdf. Accessed.

Wright, P. M., \& Snell, S. A. (1991). Toward an integrative view of strategic human resource management. Human Resource Management Review, 1(3), 203-225. http://dx.doi.org/10.1016/1053-4822(91)90015-5.

\section{Copyright Disclaimer}

Copyright for this article is retained by the author(s), with first publication rights granted to the journal.

This is an open-access article distributed under the terms and conditions of the Creative Commons Attribution license (http://creativecommons.org/licenses/by/3.0/). 